\title{
The Relationship Between Informational Outlets and Understanding: An exploration of Political Knowledge Among Generation Z
}

\author{
Alex Rupp ${ }^{1}$, Katlyn McGrann ${ }^{1}$ and Dr. Patricia Gitto ${ }^{1}$ \\ Kings Park High School, Kings Park, NY, USA \\ DOI: https://doi.org/10.47611/jsrhs.v10i2.1426
}

\section{ABSTRACT}

This study was conducted in order to investigate the effect different media outlets have on Generation Z's political knowledge in New York. Through a purposive sample, the political knowledge of 484 high school and college-aged students was tested using a Google Survey. The researcher conducted this research using a correlational study research design. Each respondent was asked to complete a survey of 16 questions, 12 of those questions testing political knowledge. The researcher calculated the correlations between the average percent correct for all media outlets and the average percent correct for respondents who claimed they acquired their political information from each media outlet (social media, newspaper, radio, locally televised news and nationally televised news). Not every age group in Generation $\mathrm{Z}$ was tested, due to the fact that many members of Generation $\mathrm{Z}$ are too young to complete the survey. Additional research that goes into more detail about which specific platform within each media outlet leads to higher political knowledge scores, could help provide a greater understanding on how different media outlets affect Generation Z's political knowledge.

\section{Introduction}

As of 2018, three hundred and twelve million Americans have access to the Internet, which is roughly $95 \%$ percent of the United States population (Clement, 2019). The Internet provides Americans with an abundance of information, though not all of that information is accurate. Anyone with access to the internet has the ability to post information to the Internet via social media, despite the fact they may not specialize in the field that they are discussing in their online posts. This leads to individuals believing false information that they are reading, which alters their knowledge on a certain topic. Misinformation is widely seen in the political world, due to the fact that certain media outlets will favor specific political parties or candidates. This leads to younger generations, in this study's case Generation Z, believing biased information. News reporters and older generations have continuously stated that Generation $\mathrm{Z}$ has little to no political knowledge when it comes to current day political events. This is widely seen due to them being surrounded by slanted or one-sided information and these members of Generation $\mathrm{Z}$ not knowing what to believe.

The purpose of this study is to find out which media outlet leads to the highest levels of political knowledge in Generation Z. This study is focused on members of Generation $Z$ due to the lack of research performed on Generation Z's political knowledge. Only basic studies have been conducted on Generation Z that test Generation Z's political behaviors, so this study will add to the very small and limited field. In the end, this study will show where members of Generation $\mathrm{Z}$ should acquire their political news. 


\section{Literature Review}

\section{Political Knowledge}

For this study, the researcher will be adopting Delli Carpini and Keeter's definition of political knowledge. Their definition states that political knowledge is "the range of factual information about politics that is stored in long-term memory" (Carpini \& Keeter, 1996). Political knowledge is going to be researched through the question "How is Generation Z's political knowledge in New York affected by the media outlet in which they acquire their information?"

\section{Partisan News}

The media in the twenty-first century has been said to contain biased news that leans in favor of certain political parties. This biased news is said to affect political knowledge in many ways. Partisan news is beginning to become more prevalent in current day media because of the divide between political parties in United States politics. A study conducted by Delia Baldassarri, an expert sociologist, found that people are becoming more extreme in their political identities and they are embracing their beliefs more than before. Also, it showed that new people joining the party are more willing to work with other political parties, rather than work against them (Baldassarri, 2011). This translates into partisan news because even though new individuals in the political world will work across political lines, the majority of individuals in positions of power will not. When people are extreme in their political identities, they will slant news reports to favor their own party. It has been proven, through a survey of 584 individuals, that the more media one consumes, the higher their political knowledge will be (Carbo, 2012). Partisan media also affected adult's political knowledge differently, depending on their political parties. For example, individuals who consumed conservative media had lower levels of liberal political knowledge and higher levels of conservative political knowledge. Individuals who consumed liberal media had higher levels of nonpartisan knowledge, but no effect on conservative knowledge (Carbo, 2012). This could be due to the fact that when conflicting sides to an argument are introduced, the individual consuming the information does not know what side to believe.

\section{Uninformed Voters}

When American citizens place votes without being politically informed, it can tip the scales of elections in favor of certain political parties. Overall, the general population of the United States is politically uninformed on the ideologies of the political parties and most Americans do not know where these parties stand on issues (Fowler \& Margolis, 2014). It has been found that democratic candidates actually do $2 \%$ better if their voters are politically uninformed. Other candidates, however, do 5\% better in political polls if their voters are politically informed (Bartels, 1996). In the United States elections, it has been found that if voters are more politically informed, they are more likely to vote for their own party no matter what. Even if they align with the policies of the other party's candidate, they will still vote for their party statistically (Forgette \& Platt, 1999). An overwhelming number of people vote based on party, without looking at the policy of the candidate, which does not allow candidates who actually align with the values of the American population to be elected (Highton, 2010).

\section{Media Outlets Effect on Political Knowledge}

In the United States, about 50\% of its citizens absorb their news from televised programs (Matsa, 2018). This makes television the largest news outlet in the United States. Many studies have cross analyzed political knowledge and the viewing of cable television. When examining the effects of political satirical shows and political news programs on one's political knowledge, it was found that viewing political news on the television decreases political knowledge. (Lawrence, 2013). This data was collected by Cooper Lawrence, an expert Psychologist, using a survey method of 104 graduate level students from a Southern University and a Northeastern University. In addition, it was found through a study of 400 individuals in New York through telephone interviews, that less-educated individuals who paid 
more attention to political televised programming reported lower levels of political knowledge (Kim, 2001). This is in agreement with Lawrence's conclusions that viewing political television leads to lower levels of political knowledge, but Kim's study goes into more detail.

Access to the Internet has been found to affect political knowledge in various ways. In some cases, the mere access to the Internet provided a weak but positive increase in political knowledge, compared to adults that did not have access to the Internet (Starling, 2014). The more that the Internet was used, the higher the levels of political knowledge among young people were reported (McAllister, 2016). When it comes to self-perceived political knowledge, it was found that the more political news a graduate student consumed, the more politically informed they believed they were (Gajora, 2011). Another study concluded that there is a weak, but positive correlation between home Internet access and political knowledge (Shaker, 2009). Even though the correlation was weak, it still follows the overall trend that Internet access leads to higher levels of political knowledge.

Many experts have analyzed how receiving and reading newspapers affect political knowledge. Broadcast news outlets have led to higher levels of knowledge over print news outlets, like newspapers. Also, it was found that broadcast news led to higher or advanced levels of current political knowledge, over fundamental political knowledge. In simpler terms, the study concluded that reading newspapers does not lead to higher levels of political knowledge compared with other media outlets (Garramone \& Atkin, 1986). Additionally, home newspaper delivery is positively correlated with both local and national political knowledge. This shows that people who read the newspaper tend to have higher levels of political knowledge (Shaker, 2009). An analysis of how the newspapers The Washington Post and The New York Times affected political knowledge and political opinions found that both newspapers had no effect on a subject's ability to answer factual questions about politics. (Gerber, Karlan, \& Bergan, 2009). Despite the fact that Gerber et al. found that there was no correlation between political knowledge and acquiring knowledge from newspapers, an overwhelming number of studies found that newspapers lead to lower levels of political knowledge. This is in comparison with other forms of media outlets such as radio news, television news and news acquired on the Internet.

\section{Generation Z}

Generation Z consists of individuals born from 1997 to the present day (Dimock, 2019). This generation is predicted to be the most educated and ethnically diverse generation in history (Fry \& Parker, 2018). These members of Generation $\mathrm{Z}$ hold similar political beliefs to Millennials, but Generation $\mathrm{Z}$ is more extreme and overwhelmingly liberal in their beliefs (Parker, Graf \& Igielnik, 2019). On the Republican side of Generation Z, they are considered to be more accepting of other races over the older Republicans in the party. Also, Generation Z Republicans tend to be more accepting of climate change, which is a normally liberal dominated topic (Parker et al., 2019). Also, it was found that $52 \%$ of Generation Z Republicans believe the government should act to solve problems more efficiently. This same belief is only held with 38\% of Millennial Republicans and 29\% of Generation X. (Parker et al., 2019). This shows the drastic divide in the ideologies of Generation $\mathrm{Z}$ compared to older generations and this is just in one political party. Members of Generation $Z$ hold similar views to Millennials when it comes to same sex marriage. $48 \%$ of Generation $\mathrm{Z}$ and $47 \%$ of Millennials believe that same sex couples should be allowed to get married in the United States (Parker et al., 2019). It can be assumed that statistics for Millennials are similar to Generation $Z$ when it comes to the rights of individuals in the United States. Generation $\mathrm{Z}$ casted 4 million votes in 2018 and the number of eligible voters in this generation increases each year. In 2020, they will account for $10 \%$ of all eligible voters (Fry \& Parker, 2018). This makes the political behaviors of the members of Generation Z important to analyze, considering they will eventually become the future of voting adults in upcoming elections. The major gap in the field of political knowledge is Generation Z. There have been little to no reputable studies conducted on Generation Z, which is not acceptable due to the fact that Generation $\mathrm{Z}$ will become a large percentage of the voting population in the United States. This gap will be filled by this study addressing Generation Z's political knowledge and it will also add to the field of research by showing what media outlet leads to the highest levels of political knowledge. 


\section{Methods}

This research was conducted through a correlational study, which is defined as a study that analyzes how two or more factors affect one another (Leedy and Omrod, 2016). This research design was used because it was the researcher's goal to determine correlations between political knowledge and the media outlet in which Generation $\mathrm{Z}$ obtains their information from. In order to gain participants, the researcher used purposive sampling, which is defined as subjects being chosen to represent a larger population or group (Leedy and Omrod, 2016). This process was used to gain subjects because the test subjects represented a larger population, which was Generation Z in New York. The researcher hypothesized that individuals who look at political news on social media will have lower levels of political knowledge.

\section{Participants}

For this research study, participants were selected based on age and the fact that they live in New York. All members of Generation Z, $N=90.55$ million individuals, were represented in this study through $n=484$ participants (Duffin, 2019). The researcher had to invalidate 14 responses due to the respondents being out of the age range or the subject entering an invalid birth year. The subjects came from 6 high schools and 6 colleges across New York State. Subjects in high school were found by the researcher contacting schools in New York State that have the AP Capstone program and asking their help to distribute surveys in their school. College and high school students were chosen to represent Generation $\mathrm{Z}$ because the majority of individuals at the schools fall in the age range needed for this study. If they answered the survey and they were out of the age range, their score was invalidated and not included in analysis. Subjects at the college level were selected by the researcher emailing the Political Science Dean/Chair at randomly selected colleges and asking them to help distribute the survey. If the Dean/Chair was not available, a professor was selected at random as the main contact point for the school's participation in the study. Participants' race, ethnicity and economic status was not necessary data, so it was not included in the survey. Age and gender were asked of all participating subjects. Out of all the subjects $39.3 \%$ were male $60.3 \%$ were female, $0.4 \%$ were other and $0.7 \%$ did not respond to the gender question. The age range of all participants ranged from 14-23 years of age. The standard deviation of all participants' age was 91.84377456 . In one of the high schools, students were offered community service to complete the survey, but participation was not mandatory.

\section{Materials}

Participants responded to 14 out of the 16 survey questions in a multiple choice format (see appendix A). For the remainder of the questions, one question was a short answer (birth year) and one question was a "check all that apply" question. The survey was completed online and students were given access to the surveys by an email from a professor or a teacher. Other participants were given access to the survey through a link posted on Google Classroom or Blackboard. The electronic device used to complete the survey was up to the participant's discretion.

The subjects that participated in the study answered survey questions from Cooper Lawrence's doctoral dissertation (Lawrence, 2013), Brooke Carbo's Master's Theses (Carbo, 2012), and Eunyi Kim's doctoral dissertation (Kim, 2001). Questions were pulled from these studies because their surveys contained questions the researcher deemed necessary to test political knowledge. The only questions that did not test political knowledge were the gender and birth year questions. Answers were coded based off of a correct response, incorrect response and no answer $(0=$ no response, $1=$ correct, $2=$ incorrect).

\section{Procedure}

The researcher began by completing the "Protecting Human Research Participants Online Training" (see appendix B). From there, the researcher continued by applying and gaining approval from an Institutional Review Board (see appendix C). This allowed the researcher to confirm that the study was ethical and not posing physical or mental risks 
to the subjects that were participating in the research. After approval, the researcher designed a survey that took questions from the previously listed researchers. The survey questions were altered to fit the current political leaders, instead of the political leaders when Lawrence's study was conducted (Lawrence, 2013). Students at two high schools were not allowed to participate in the research until they had a consent form signed by a parent (See appendix D). On the first question of the survey, a link was added that included a document that was titled "Informed Consent to Participate in Research" (See appendix E). This document allows the participant to know how and where the data will be used. If the participant checked yes, they agreed that their data can be used. After the creation of the survey, the researcher contacted 12 political science chairs and deans at colleges across New York State. In that email, the researcher asked the dean/chair to aid them in distributing the survey (see appendix F). Next, the researcher contacted 12 high schools across New York State that had the AP Capstone curriculum in their school. If the AP Research teacher's email was accessible, they were contacted, otherwise the principal of the school was emailed (see appendix G). The email to each high school was the same and the email to each college was also the same. The researcher contacted 12 schools on each educational level because they hoped that at least half would agree to participate in the study. In the colleges, the professors emailed or posted the survey to their class websites. The students took the survey on the electronic device of preference. In the high schools, the students took the survey on their phones or school provided computers.

\section{Measures}

Political Knowledge was measured through twelve questions that tested political knowledge. One question was invalidated due to the question answer being switched because of an update in United States gun laws. The survey questions tested political knowledge by asking questions about current political leaders, political campaigns, laws in the United States, and United States Government agencies. Only quantitative data was collected, which is defined as data that is numerical in nature or can be reduced to numbers (Leedy and Omrod, 2016). Quantitative data was collected due to the fact that the researcher decided to use scores on a political test to test political knowledge. The researcher decided to do this because it allows there to be no perceptions about political knowledge involved in the study and it allowed the participant's actual political knowledge to be tested.

Political knowledge was mathematically calculated by coding the data $(0=$ no response, $1=$ correct, $2=$ incorrect). Next, the Countif feature on Google Sheets was used to count the number of correct responses for each question, this was repeated for all responses and then for each individual media outlet. From there, the percent correct for each question per media outlet was calculated. All percentages were rounded to the hundredth decimal place value for analysis.

From there, the researcher calculated the correlation between the mean percent correct for each individual media outlet and the combined percent correct for all media outlets, using the correlation coefficient formula.

\section{Limitations}

Even though the design of this study matches many other studies conducted by world renowned experts and researchers, there are still some limitations that need to be addressed. One limitation was that when analyzing studies for survey questions for their own study, they could only find questions that were previously tested on adults and not members of Generation Z. This could have led to the survey questions being at a higher level for adults, so they could have been too hard for the younger generation. Another limitation was that the study could not include all age groups within Generation $\mathrm{Z}$ because they were too young. The researcher included participants at the high school and college level, but not at the middle school level, due to their age and lack of exposure to laws and current events. The final limitation the researcher addressed is the fact that only 12 questions were asked regarding political knowledge. This was done to prevent survey fatigue, but it may have limited chances for the subjects to display their political knowledge. 


\section{Results}

Prior to analyzing the data, the researcher created figures to aid in analysis. Out of the 484 participants in the study, 470 met the criteria for analysis. The researcher separated the data into 6 categories (one category per media outlet). The results for the individuals that got their information from an unnamed political outlet were not analyzed, because they did not fit into a specific media outlet.

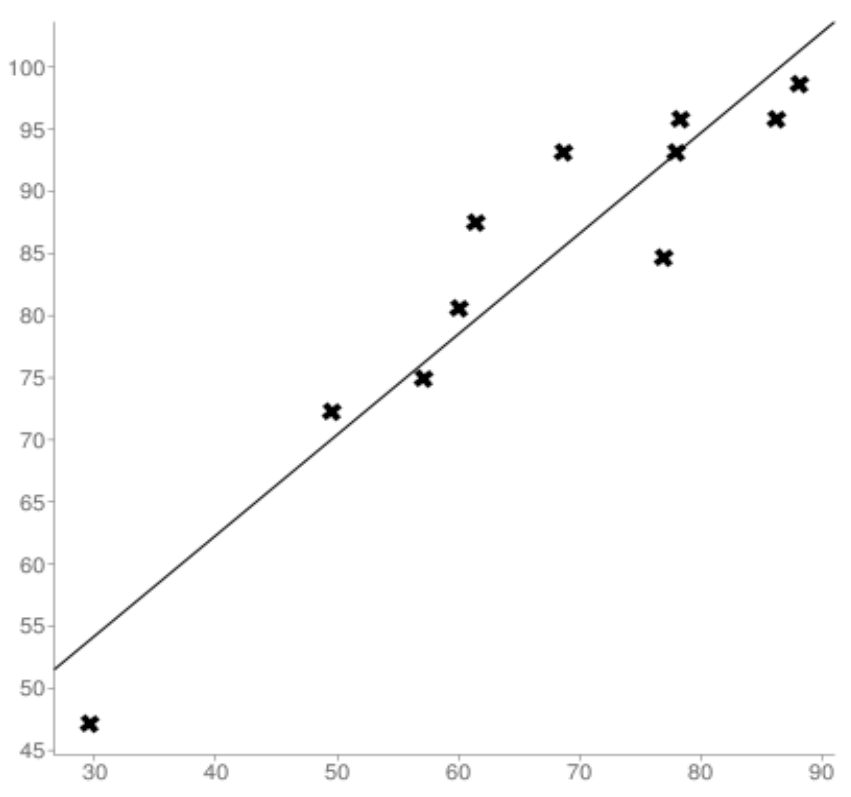

Newspapers vs. All Data

Figure 1

Note. Figure 1 shows a scatterplot of the correlation coefficients of Newspapers vs. All Data. The average percent correct for each question on the political knowledge test was used for the correlation coefficients. The scatterplot above shows a strong and positive correlation between the percentage of questions subjects got correct that received their information from Newspapers vs. the percentage of questions subjects got correct overall. 


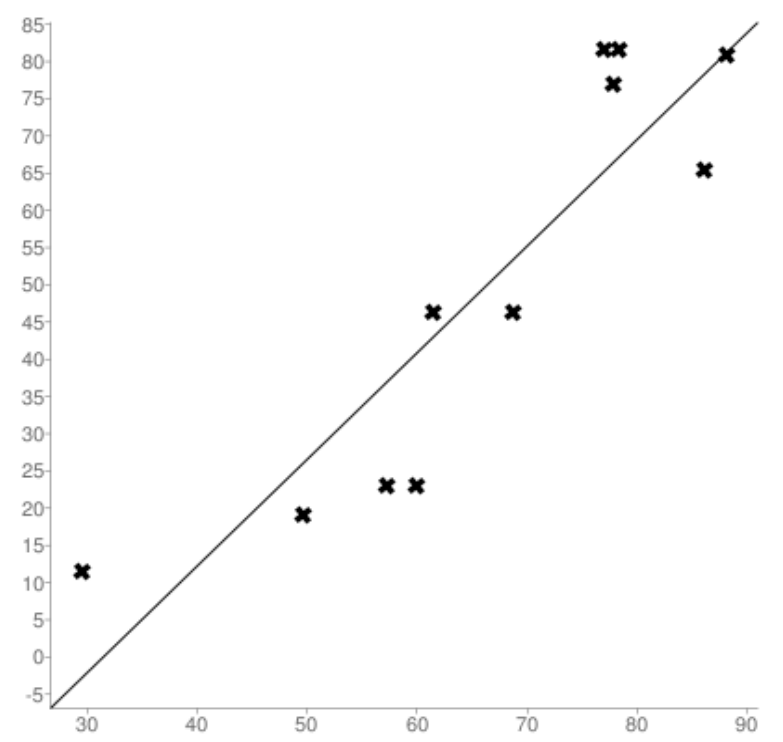

Figure 2

Local Television News vs All Data

Note. Figure 2 shows a scatterplot of the correlation coefficients of Locally Televised News vs. All Data. The average percent correct for each question on the political knowledge test was used for the correlation coefficients. The scatterplot above shows a strong and positive correlation between the percentage of questions subjects answered correctly that received their information from Locally Televised News vs. the percentage of questions subjects answered correctly overall.

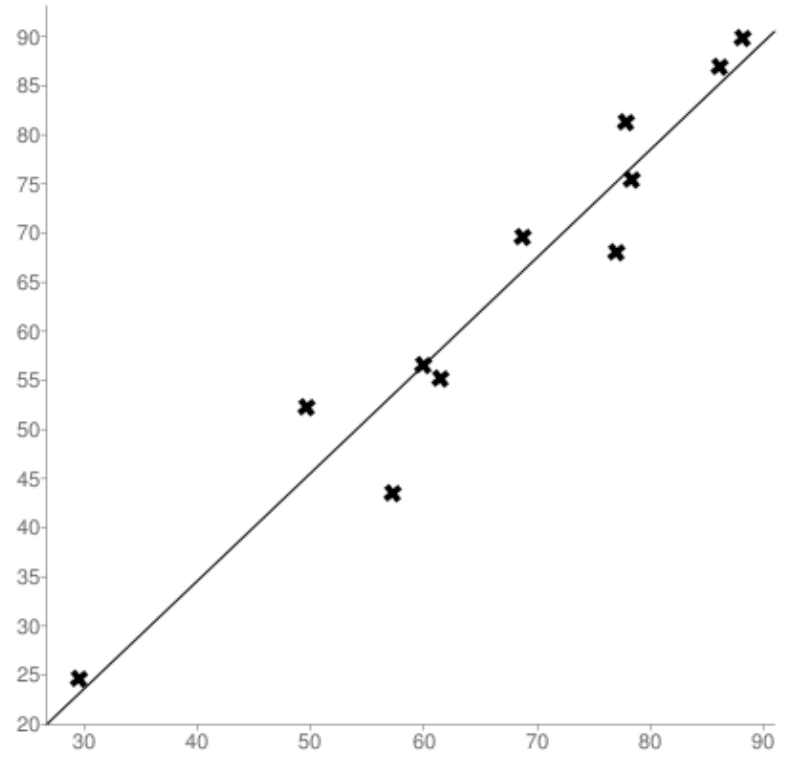

Nationally Televised News vs. All Data

\section{Figure 3}

Note. Figure 3 shows a scatterplot of the correlation coefficients of Nationally Televised News vs. All Data. The average percent correct for each question on the political knowledge test was used for the correlation coefficients. The 
scatterplot above shows a strong and positive correlation between the percentage of questions subjects answered correctly that received their information from Nationally Televised News vs. the percentage of questions subjects answered correctly overall.

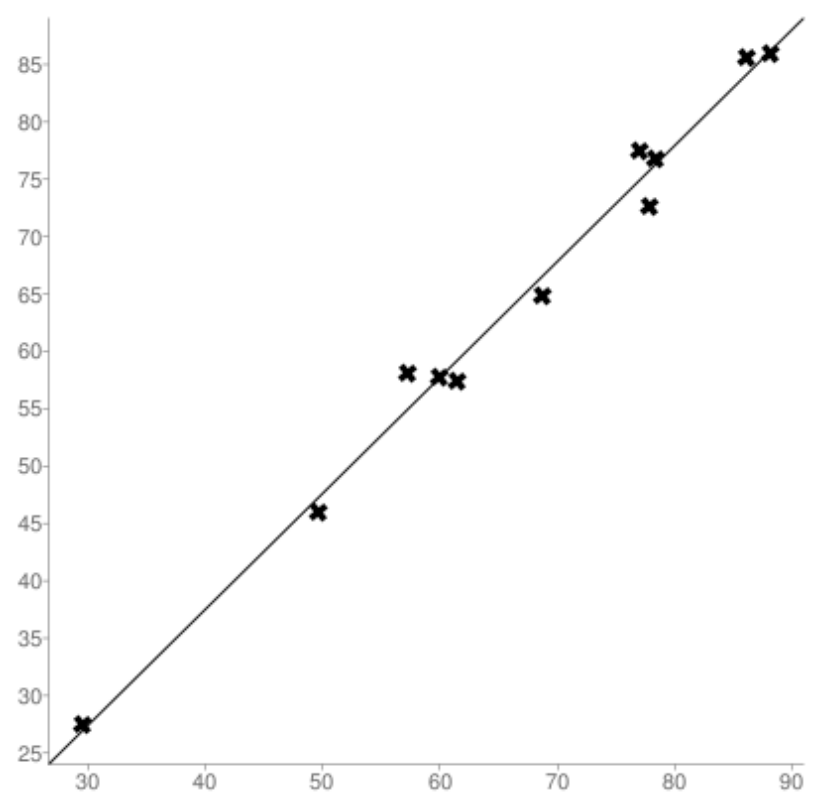

Social Media vs. All Data

\section{Figure 4}

Note. Figure 4 shows a scatterplot of the correlation coefficients of Social Media vs. All Data. The average percent correct for each question on the political knowledge test was used for the correlation coefficients. The scatterplot above shows a strong and positive correlation between the percentage of questions subjects answered correctly that received their information from Social Media vs. the percentage of questions subjects answered correctly overall. 


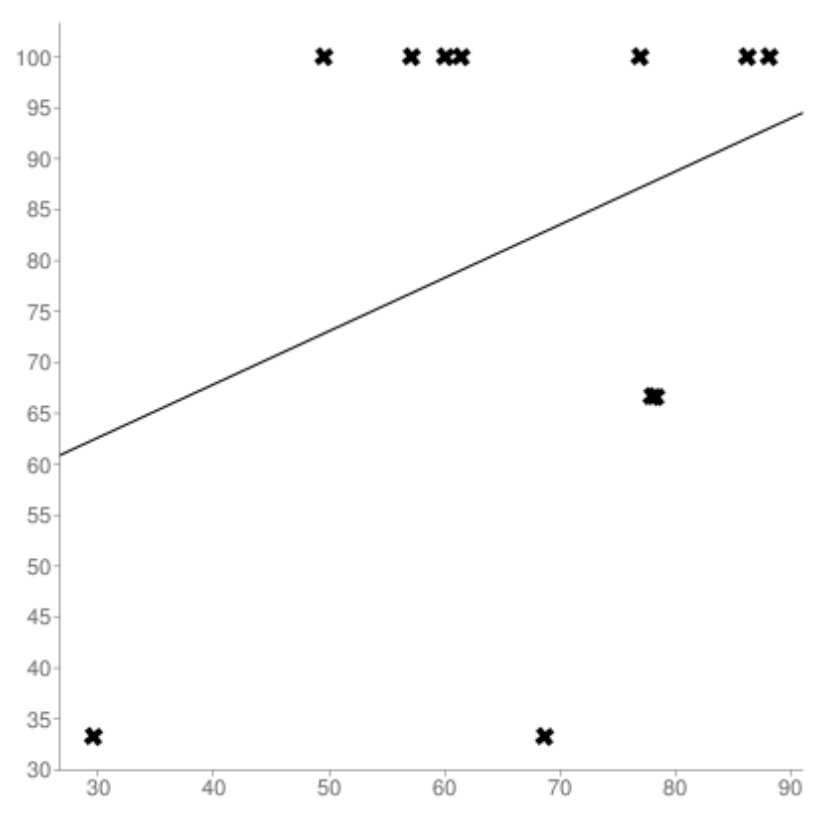

\section{Figure 5}

Note. Figure 5 shows a scatterplot of the correlation coefficients of Radio vs. All Data. The average percent correct for each question on the political knowledge test was used for the correlation coefficients. The scatterplot above shows a weak, but positive correlation between the percentage of questions subjects answered correctly that received their information from the Radio vs. the percentage of questions subjects answered correctly overall.

Figures 1 through 5 analyzed the correlation coefficient for each media outlet. The correlation between Social Media and all responses had the strongest correlation, with a correlation coefficient of 0.9940503218 . The weakest correlation was found for radio, with a correlation of 0.3333236187 .

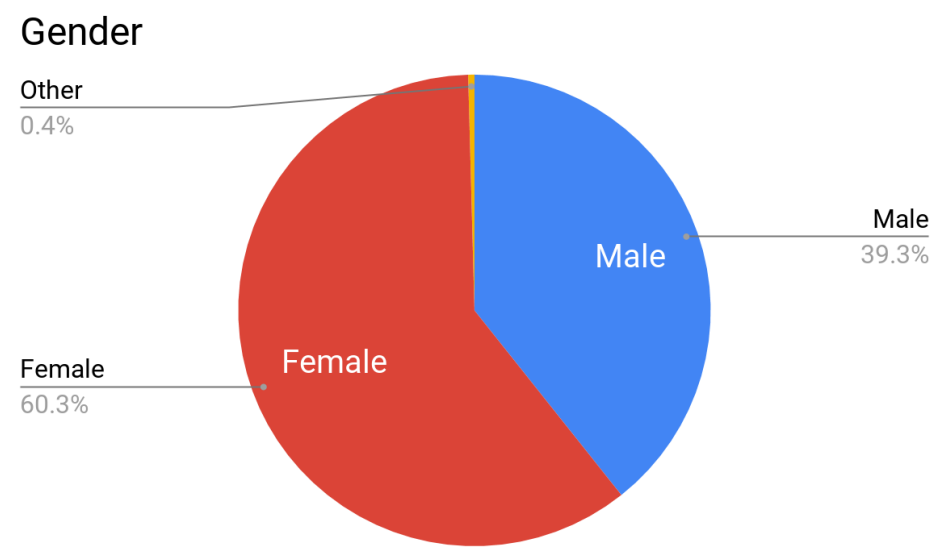

Gender

\section{Figure 6}

Note. Figure 6 shows the gender of every participant in the study. The figure shows that 39.3 percent of participants were male, 60.3 percent were female and 0.4 percent of the participants classified their gender as "other". 


\section{Media Outlet}

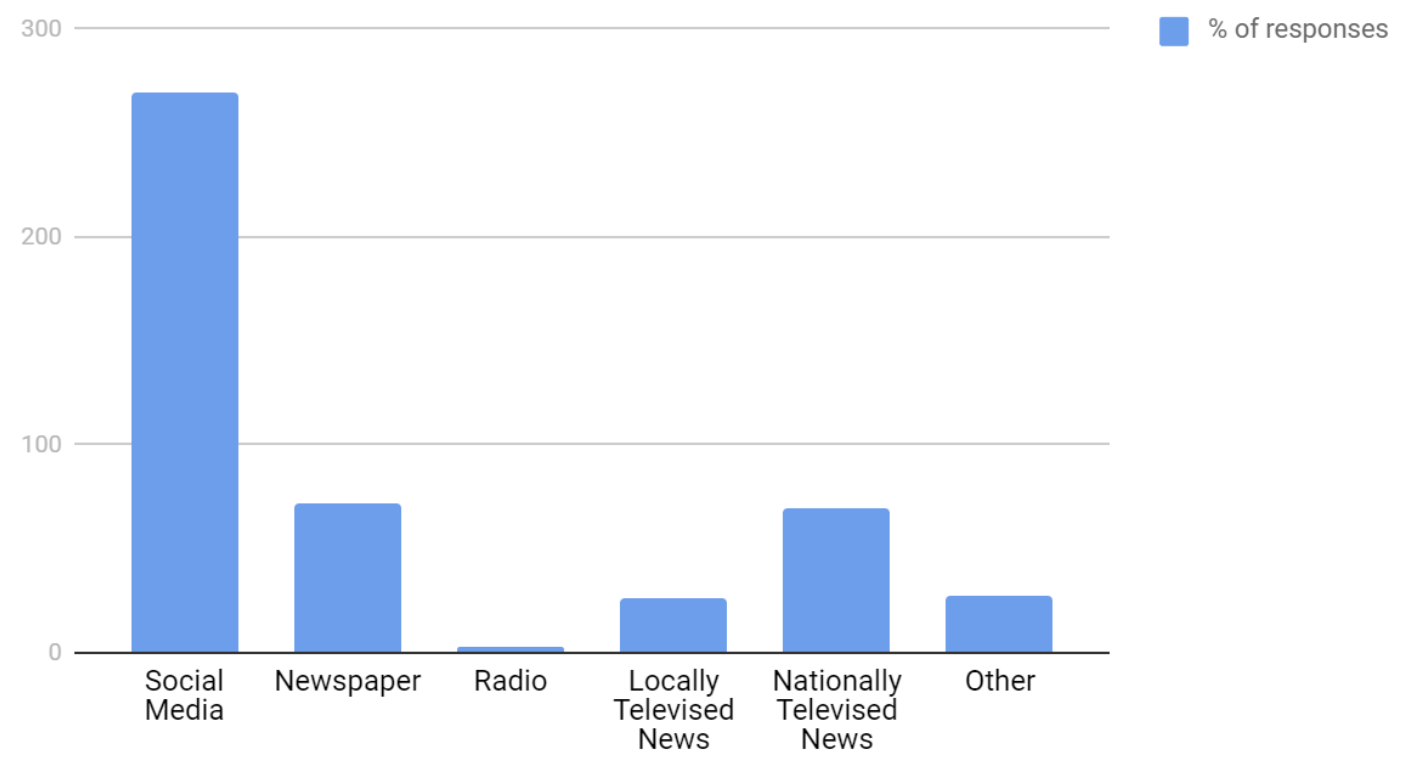

Media Outlets

\section{Figure 7}

Note. Figure 7 shows where each subject acquires their political information. The options participants were given to choose from where they acquired their political information was Social Media, Newspapers, Radio, Locally Televised News, Nationally Televised News or other.

\section{Table 1}

Percent Correct per Media Outlet

\begin{tabular}{|c|c|c|c|c|c|c|}
\hline Question \# & $\begin{array}{l}\text { Average } \% \\
\text { correct for all }\end{array}$ & $\begin{array}{c}\text { Newspaper }(\% \\
\text { correct })\end{array}$ & $\begin{array}{l}\text { Local Tele- } \\
\text { vised News } \\
(\% \text { correct })\end{array}$ & $\begin{array}{c}\text { National Tele- } \\
\text { vised News } \\
\text { (\% correct) }\end{array}$ & $\begin{array}{l}\text { Social Media } \\
\text { (\% correct) }\end{array}$ & $\begin{array}{c}\text { Radio } \\
(\% \text { correct })\end{array}$ \\
\hline 5 & $61.5 \%$ & $87.5 \%$ & $46.2 \%$ & $55.1 \%$ & $57.4 \%$ & $100 \%$ \\
\hline 6 & $88.1 \%$ & $98.6 \%$ & $80.8 \%$ & $89.9 \%$ & $85.9 \%$ & $100 \%$ \\
\hline 7 & $78.3 \%$ & $95.8 \%$ & $81.5 \%$ & $75.4 \%$ & $76.7 \%$ & $66.7 \%$ \\
\hline 8 & $57.2 \%$ & $75 \%$ & $23.1 \%$ & $43.5 \%$ & $58.1 \%$ & $100 \%$ \\
\hline 9 & $49.6 \%$ & $72.2 \%$ & $19.2 \%$ & $52.2 \%$ & $45.9 \%$ & $100 \%$ \\
\hline 10 & $77 \%$ & $84.7 \%$ & $81.5 \%$ & $68.1 \%$ & $77.4 \%$ & $100 \%$ \\
\hline 11 & $68.7 \%$ & $93.1 \%$ & $46.2 \%$ & $69.6 \%$ & $64.8 \%$ & $33.3 \%$ \\
\hline
\end{tabular}




\begin{tabular}{|c|c|c|c|c|c|c|}
\hline 12 & $60 \%$ & $80.6 \%$ & $23.1 \%$ & $56.5 \%$ & $57.8 \%$ & $100 \%$ \\
\hline 13 & $77.9 \%$ & $93.1 \%$ & $76.9 \%$ & $81.2 \%$ & $72.6 \%$ & $66.7 \%$ \\
\hline 14 & $86.2 \%$ & $95.8 \%$ & $65.4 \%$ & $87 \%$ & $85.6 \%$ & $100 \%$ \\
\hline 15 & $29.6 \%$ & $47.2 \%$ & $11.5 \%$ & $24.6 \%$ & $27.4 \%$ & $33.3 \%$ \\
\hline
\end{tabular}

Note. Table 1 shows the percent of questions participants answered correctly. The table is further broken down by the media outlet they acquired their political information from (Media outlets that were not listed in question 4 were excluded).

\section{Table 2}

Correlation Coefficient

\begin{tabular}{|c|c|c|c|c|}
\hline & & & \\
Newspaper & Locally Televised News & Nationally Televised News & Social Media & Radio \\
\hline 0.9409491087 & 0.8942041012 & 0.9663363251 & 0.9940503218 & 0.3333236187 \\
\hline
\end{tabular}

Note. Table 2 shows the correlation coefficient for each media outlet. All correlation coefficients were cross analyzed with the combined average of the percent of questions that were answered correctly by the participants.

\section{Table 3}

Mean

\begin{tabular}{|c|c|c|c|c|c|}
\hline Newspaper & $\begin{array}{c}\text { Locally Televised } \\
\text { News }\end{array}$ & $\begin{array}{c}\text { Nationally Televised } \\
\text { News }\end{array}$ & Social Media & Radio & All Outlets \\
\hline $83.96 \%$ & $50.49 \%$ & $63.92 \%$ & $64.51 \%$ & $81.82 \%$ & $66.74 \%$ \\
\hline
\end{tabular}

Note. Table 3 shows the mean test scores for each media outlet. The percent right for each question was averaged per media outlet to get the mean. Participants who used Newspapers as their primary media outlet for political news scored the highest with $83.96 \%$ correct. The media outlet that had the lowest scores was Locally Televised News with $50.49 \%$ correct.

\section{Table 4}

Standard Deviation

\begin{tabular}{|c|c|c|c|c|c|}
\hline & Locally Televised & Nationally Televised & & \\
Newspaper & News & News & Social Media & Radio & All Outlets \\
\hline 15.02 & 27.93 & 19.80 & 17.73 & 27.35 & 17.43 \\
\hline
\end{tabular}

Note. Table 4 shows the standard deviation of the average percent correct for each media outlet. The largest standard deviation was Locally Televised News with 15.02 and the smallest was Newspapers with 27.93, which means that the newspaper category had the smallest variation in the data. 


\section{Discussion}

The purpose of this research was to determine which media outlet leads to higher levels of political knowledge in Generation Z. Prior research has been conducted on the correlation between media outlets and political knowledge, but there has been little to no studies conducted on Generation Z. In order for the researcher to accomplish their research goal, they had to first find out where the subjects acquired their political news. Next, the researcher had to test each subject's political knowledge by giving them a political knowledge exam. Finally, the researcher had to see if there was a correlation between where the subject acquired the information and their political knowledge scores.

Figures 1-5 showed the correlation between political knowledge and where subjects acquired their information. The percent correct for questions answered by all respondents were then correlated with the percent correct for all questions answered by subjects from each individual media outlet. Figures 1-4 show a positive correlation between respondents who acquire their political information from Newspapers and the political knowledge scores for all respondents. Additionally, figures 1-4 show a strong correlation. Due to there being a numerically strong correlation, it shows that the media outlet in which you acquire your political information affects your political knowledge. The strongest correlation was between the political knowledge scores from individuals who acquire their information from Social Media and all respondents (see Figure 4). Figure 4 shows a positive and strong correlation with the correlation coefficient of 0.9940503218 . 270 out of the 470 respondents that met the criteria for analysis acquire their political information from Social Media, which was the media outlet that most of the respondents acquired their political information from (see figure 7). Social media could have had the strongest correlation due to the high number of respondents answering Social Media for question 4 (see appendix A). Figure 5 shows a positive correlation of political knowledge scores for respondents who acquire their information from the Radio and the political knowledge scores for all respondents. The correlation coefficient of 0.3333236187 shows a positive correlation, but the low number shows that the correlation was weak. The correlation could be weak due to the fact that only 3 out of the 470 responses that met the criteria for analysis responded Radio for question 4.

To determine a causation, the researcher analyzed the percent correct per media outlet for each question (see Table 1). While analyzing the percent correct per media outlet, the researcher decided not to include Radio in the analysis due to the fact that there were only three respondents who claimed to get their political information from that outlet. For question 5, there was a large variance in the number of correct responses for each media outlet (See appendix A for questions). $87.5 \%$ of subjects that acquire their information from Newspapers answered question 5 correctly compared to $46.2 \%$ of individuals that acquire their information from Local Televised News. The trend that Newspaper had the highest percent correct and Local Televised News having the least amount correct stayed consistent in most questions. This contradicts the findings of Garramone and Atkin, which found that reading newspapers does not lead to higher levels of political knowledge compared to other media outlets (Garramone \& Atkin, 1986). The researcher may have come to a different conclusion, due to the fact that Garramone and Atkin studied adults, while on the other hand, this researcher studied Generation Z.

To determine which media outlet led to the highest political knowledge scores, the researcher took the mean percent of all correct responses for each media outlet. The media outlet that scored the highest on the political knowledge exam was Newspaper with a mean of $83.96 \%$ and the media outlet that had the lowest mean was Locally Televised News with $50.49 \%$. This shows that members of Generation $\mathrm{Z}$ that acquire their political information from Newspapers have higher levels of political knowledge and are more politically informed. This result reaches the same conclusion as Shaker, which found a positive correlation between reading the newspaper and higher political knowledge scores (Shaker, 2009). The means for percent correct for the other media outlets fall in between the mean for Newspapers and Locally Televised News (see table 3). 


\section{Limitations}

The largest limitation of this study is that the subjects were asked where they acquire their political information and there was no way to confirm it. Individuals may get their political information off of social media or online newspapers without them even realizing it. This could have altered the media outlet category they were placed in, which could have altered the outcomes of the study. Another limitation is that the subjects in the study that represent Generation $\mathrm{Z}$ had different educational levels, which could have altered their political knowledge. College students have more years of education, which could alter their scores, which could alter the data as a whole.

\section{Significance}

The significance of these findings is that the results could potentially impact where members of Generation $\mathrm{Z}$ acquire their political information. The data from this study evidently showed that subjects that acquire their political information from Newspapers have higher levels of political knowledge. This data reached similar conclusions as Lee Shaker, which also concluded that acquiring political information from newspapers leads to higher levels of political knowledge (Shaker, 2009). This is significant because the researcher's data came to the same conclusions as Shaker, which shows that multiple researchers have come to the same conclusions as to where people should acquire their political information. Based on these findings, it would be recommended that members of Generation $\mathrm{Z}$ acquire their political information from Newspapers. However, the results of this study showed that the majority of participants acquire their political information from Social Media, which is an issue due to the fact that the political knowledge scores were low for participants who acquire their information from that outlet. Generation $\mathrm{Z}$ will soon fully be among the voting population in the United States, so it is necessary for them to be politically informed. Uninformed voters are dangerous in the political system because they alter the outcomes of elections. This leads to politicians that do not represent the beliefs of the American people as a whole to be elected (Highton, 2010). The findings of this study are significant because it can help show members of Generation $\mathrm{Z}$ where they should acquire their political information.

\section{Conclusion}

In today's world, the Internet is full of political information, but it is not all reliable and does not provide its users with relevant and correct information. This is due to biased media sources flooding the internet with information that only supports their political ideologies. The purpose of this study was to discover which media outlet leads to the highest levels of political knowledge in Generation Z. By finding which media outlet leads to the highest levels of political knowledge, it allows for researchers to show where Generation $\mathrm{Z}$ should acquire their information. If Generation $\mathrm{Z}$ acquires their information from Newspapers, which is the outlet that led to the highest levels of political knowledge in this study, then it would be possible that Generation Z's overall political knowledge would increase.

If this research were to be continued by another researcher, it would be recommended to explore each media outlet in more depth. Subjects were only asked which media outlet they obtain their information from, but they were not asked the specific outlet within each category. For example, a future researcher could ask where subjects acquire their information and then they could ask which specific news outlet or social media outlet they receive political news from. Additionally, if research was continued, it would be recommended that a future researcher adds more survey questions to the survey. The researcher in this study only analyzed 11 political knowledge questions (see appendix A). If additional questions were asked, it would enable a future researcher to have more of an in-depth analysis on each subject's political knowledge. 


\section{Acknowledgments}

I would like to thank my advisors Katlyn McGrann and Dr. Patricia Gitto for helping me with this project.

\section{References}

Baldassarri, D. (2011). Partisan joiners: Associational membership and political polarization in the United States (1974-2004). Social Science Quarterly, 92(3), 631-655. https://doi.org/10.1111/j.1540-6237.2011.00785.x

Bartels, L.M. (1996). Uninformed votes: Information effects in presidential elections. American Journal of Political Science, 40(1), 194-230. https://doi.org/10.2307/2111700

Carbo, B. (2012). Fragmented knowledge: Exploring the relationship between partisan media exposure and liberal, conservative and nonpartisan political knowledge (Master's thesis). Retrieved from ProQuest Dissertation and Theses database. (1519397)

Carpini, M., \& Keeter, S. (1996). What Americans know about politics and why it matters. www.jstor.org/stable/j. ctt1cc2kv1

Clement, J. (2019). Internet usage in the United States- Statistics \& facts. Statistica,www.statista.com/topics/223 7/internet-usage-in-the-united-states/

Dimok, M. (2019). Defining generations: Where Millennials end and Generation Z begins. Pew Research Center, www.pewresearch.org/fact-tank/2019/01/17/where-millennials-end-and-generation-z-begins/

Duffin, Erin. (2019). U.S. population by generation 2017. Statistica, https://www.statista.com/statistics/797321/uspopulation-by-generation/

Forgette, R. and Platt. G.J. (1999). Voting for the person, not the party: Party defection, issue voting, and processsophistication. Social Science Quarterly, 80(2), 409-421.www.jstor.org/stable/42863909

Fowler, A, and Margolis, M. (2014). The political consequences of uninformed voters. SSRN Electronic Journal, 34, 100-110. https://doi.org/10.1016/j.electstud.2013.09.009

Fry, R. and Cilluffo, A. (2019). Gen z, Millennials and Gen x outvoted older generations in 2018 midterms. Pew Research Center, https://www.pewre search.org/fact-tank/2019/05/29/Gen-z-millennials-and-gen-X-outvoted-oldergenerations-in-2018-midterms/

Fry, R. and Parker, K. (2018). Early benchmarks show 'post-millennials' on track to be most diverse, best-educated generation yet. Pew Research Center, www.pewsocialtrends.org/2018/11/15/early-benchmarks-show-post-millennials-on-track-to-be-most-diverse-best-educated-generation-yet/

Gajora, L. (2011). Effects of internet use on actual and self-perceived political knowledge, issue, certainty and political participation (Master's Thesis). Retrieved from ProQuest Dissertation and Theses database. (1494563) Garramone, G.M. and Atkin, C.K. (1986). Mass communication and political socialization: Specifying the effects. The Public Opinion Quarterly, 50, 76-86. https://doi.org/10.1086/268960 
Gerber, A. S., Karlan, D., and Bergan, D.(2009). Does the media matter? A field experiment measuring the effect of newspapers on voting behavior and political opinions. American Economic Journal: Applied Economics, 1(2), 3552. www.jstor.org/stable/25760159

Highton, B. (2010). The contextual causes of issue and party voting in american presidential elections. Political Behavior, 32(4), 453-471. https://doi.org/10.1007/s11109-009-9104-2

Kim, E. (2001). Dissecting the puzzle of knowledge gap: Media and the internet in the political knowledge gap in the 2000 presidential election campaign (PhD dissertation). Retrieved from ProQuest Dissertation and Theses database. (3026393)

Lawrence, C. (2013). The relationship between television viewing and the political knowledge and behaviors of the emerging adults (PhD dissertation). Retrieved from ProQuest Dissertation and Theses database. (3564913)

Matsa, K.E. (2018). Fewer Americans rely on TV news; what type they watch varies by who they are. Pew Research Center, https://www.pewresearch.lorg/fact-tank/2018/01/05/feweR-americans-rely-on-tv-news-what-tyPe-theywatch-varies-by-who-they-are/

McAllister, I. (2016). Internet use, political knowledge and youth electoral participation in Australia. Journal of Youth Studies, 19, 1220-1236.https://doi.org/10.1080/13676261.2016.1154936

Mitchell,A., Barthel, M., Gottfried, J. and Shearer, E. (2016). The modern news consumer. Pew Research Center, https://www.journalism.org/2016/ 07/07/the-modern-news-consumer/

Parker, K., Graf, N. and Igielnik, R. (2019). Generation Z looks a lot like Millenials on key social and political issues. Pew Research Center, https://www.pewsocialtrends.org/2019/01/17/generation-z-looks-a-lot-like-millennials-on-key-social-and-political-issues/

Shaker, L. (2009). Citizens local political knowledge and the role of media access. Journalism \& Mass Communication Quarterly, 86(4), 809-826. https://doi.org/10.1177/107769900908600406

Starling, A. (2014). Kids these days: Political knowledge, young people, and the internet (PhD dissertation). Retrieved from ProQuest Dissertation and Theses database. (3620175) 